\title{
Acoustic detection of organic enrichment in sediments at a salmon farm is confirmed by independent groundtruthing methods
}

\author{
D. J. Wildish ${ }^{1, *}$, J. E. Hughes-Clarke ${ }^{2}$, G. W. Pohle ${ }^{3}$, B. T. Hargrave ${ }^{4}$, L. M. Mayer ${ }^{5}$ \\ ${ }^{1}$ Biological Station, Fisheries \& Oceans Canada, 531 Brandy Cove Road, St. Andrews, New Brunswick E5B 2L9, Canada \\ ${ }^{2}$ Department of Geodesy \& Geomatics Engineering, University of New Brunswick, PO Box 4400, Fredericton, \\ New Brunswick E3B 5A3, Canada \\ ${ }^{3}$ Huntsman Marine Science Centre, 1 Lower Campus Road, St. Andrews, New Brunswick E5B 2L7, Canada \\ ${ }^{4}$ Bedford Institute of Oceanography, Fisheries \& Oceans Canada, Dartmouth, Nova Scotia B2Y 4A2, Canada \\ ${ }^{5}$ Darling Marine Center, University of Maine, 193 Clarks Cove Road, Walpole, Maine 04573, USA
}

\begin{abstract}
Acoustic backscatter contrast in depositional sediments under salmon farm cages in the Bay of Fundy, Canada, was correlated with localized changes in (unknown) sediment geotechnical properties, as indicated by 4 independent measures of organic enrichment. Sediment total sulfides and redox potentials, enzyme hydrolyzable amino acids, sediment profile imaging and macrofaunal samples, taken at mid-cage positions, each rejected the null hypothesis that salmon cage footprints, defined acoustically as high backscatter areas, were indistinguishable from nearby reference areas. Acoustic backscatter imaging appears capable of mapping organic enrichment in depositional sediments caused by excessive inputs of salmon farm wastes associated with intensive aquaculture.
\end{abstract}

KEY WORDS: Organic enrichment $\cdot$ Multi-beam acoustics $\cdot$ Sedimentary sulfides $\cdot$ Sediment profile imaging $\cdot$ Aquaculture

\section{INTRODUCTION}

Organic enrichment in sediments results from an enhanced supply of dissolved and particulate organic matter, which usually instigates a proportionate microbial response. The organic matter supply may be of natural origin, e.g. from phytoplankton or a whale carcass reaching the seabed, or from anthropogenic sources (e.g. municipal and industrial effluents, fish plant processing, agriculture and mariculture wastes). Many aspects of the ecology of organic enrichment in sediments are relatively well known, e.g. microbiology (Poole et al. 1978), macrofaunal responses (Pearson \& Rosenberg 1978, Gowen \& Bradbury 1987, Gray et al. 2002) and pelagic-benthic coupling (Cloern 2001).

One area of organic enrichment studies which has remained problematic and unresolved is the determination of the geographic (=spatial) extent of organic enrichment effects in sediments. This arises because of inherent problems in classical sampling with grab or corer, even if a few radial transects from the organic enrichment source are used. Grab samplers are remote devices of relatively small sampling area $\left(<0.5 \mathrm{~m}^{2}\right)$ whose sampling position is usually not accurately known. The high cost in time and expertise required for processing samples, e.g. for macrofaunal identification, limits the number of samples that can be analyzed. This means that the area that can be accurately mapped, according to the 4 levels of organic enrichment gradient of Pearson \& Rosenberg (1978), is therefore very limited. By contrast, acoustic methods offer comprehensive spatial coverage of sizeable areas (>40 $\mathrm{km}^{2} \mathrm{~d}^{-1}$ ) of accurately geo-referenced data.

During preliminary, multibeam acoustic surveys at salmon farming leases in Newfoundland (Tlusty et al. 2000) and New Brunswick (Hughes-Clarke 2001), it was noticed that backscatter images studied from the net depositional sediments showed the individual 
salmon cage 'footprint' as a contrast (white area, high backscatter) to the darker background image (low backscatter), characteristic of depositional sediments. The inference was that the high backscatter was caused by localized changes in sediment geotechnical properties, due to organic enrichment resulting from the very high inputs of salmon faeces and waste food under farms.

This work is the first step in establishing whether the acoustic methods briefly described herein can be developed further to map organic enrichment effects in soft sediments. The aim of this study was to check the inference mentioned above by testing the null hypothesis that the acoustically defined areas of high backscatter were not the direct result of organic enrichment events in sediments.

\section{MATERIALS AND METHODS}

Acoustic surveys were completed from RVs 'Mary-O' and 'Heron' on 27 July 2001 and 9 October 2002 around a farm site in Lime Kiln Bay, which opens to the Bay of Fundy (Fig. 1). In October 2002, RV 'Heron' was equipped with a $300 \mathrm{kHz}$ multibeam sonar (vertically mounted Simrad EM3000), and in July 2001, RV 'Mary-O' deployed a $200 \mathrm{kHz}$ pole-mounted sidescan (Knudsen 320B/.P with Airmar staves). Both systems produce estimates of bottom backscatter strength, correcting for source level, beam patterns, spherical

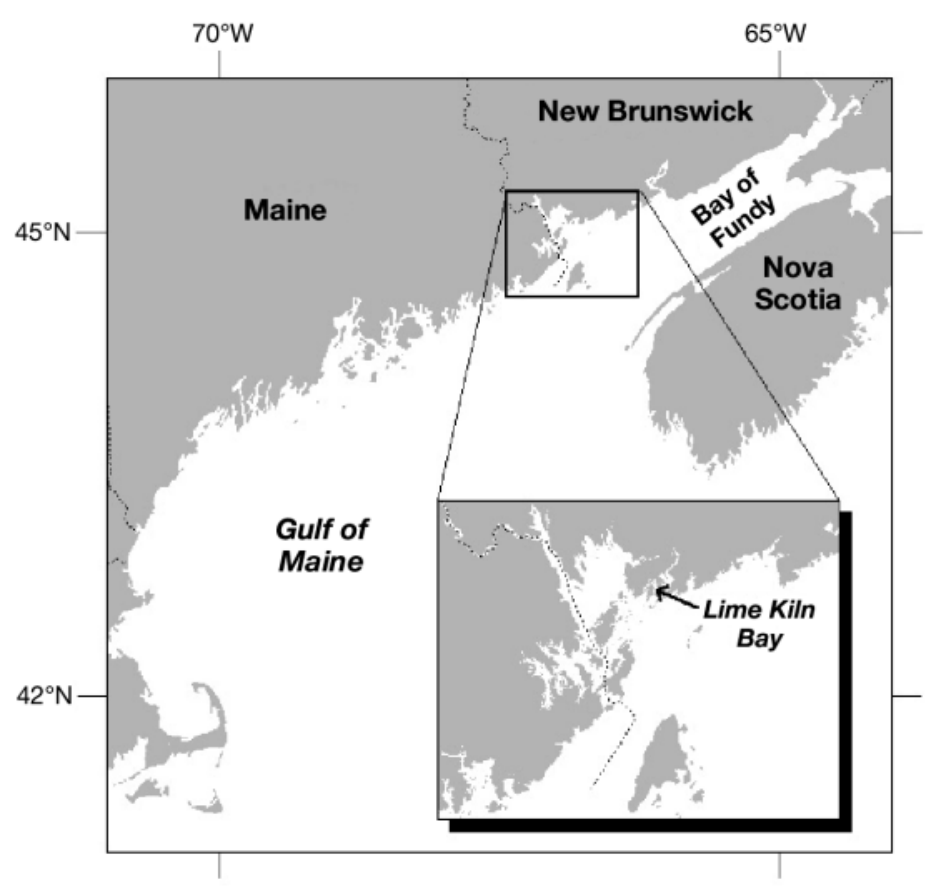

Fig. 1. Map of sampling site spreading and attenuation, ensonified area and grazing angle (Hughes-Clarke 1994, Hughes-Clarke et al. 1996). Due to imperfect knowledge of absolute calibration levels, the backscatter strength estimates at the reference and farm sites have been assumed to be the same, and the $200 \mathrm{kHz}$ data-bulk shifted to match the $300 \mathrm{kHz}$ results. The data obtained were processed digitally to produce a map of bottom backscatter strength in which high backscatter was indicated by a lighter colour. A gross correction for grazing angle was applied, but this did not remove all the residual shiptrack parallel stripes, which reflects both variations in the shape of the angular response and imperfections in the beam-pattern model used. The mean backscatter strength is dependent on the exact grazing angle, where in the cage footprint it is measured, and on the absolute calibration. Backscatter strength was measured in a $5 \times 5 \mathrm{~m}$ area near the centre of the cage footprint, aided by graphical software (SwathEd, developed at the University of New Brunswick) to select the highest values. The value in decibels $(\mathrm{dB})$ for each pixel was averaged. The mean for each location was found to be reproducible within $0.2 \mathrm{~dB}$. High backscatter (white) is indicated by less negative values, and low backscatter (dark) by more negative values.

Groundtruthing surveys were conducted from RV 'Pandalus III' on 26 July 2001 and 9 September 2002, at the same farm site, moored to cages (farm) or a floating pontoon $50 \mathrm{~m}$ from the nearest cage (reference location). The maximum permissible stocking density at New Brunswick salmon farms is $18 \mathrm{~kg} \mathrm{~m}^{-3}$. The cages at the salmon farm we investigated were $50 \mathrm{~m}$ in diameter; the farm was 3 mo into its smolt year of production in 2001, and nearing the end of its production cycle in 2002 (market year). Thus, in 2002 a higher fish biomass was present and, consequently, feeding rates would be higher than in 2001. Five farm cages were sampled at the cage mid-point on each date, and an equal number of reference samples within a $1 \mathrm{~m}^{2}$ quadrat $50 \mathrm{~m}$ away from the cages. Sampling was achieved by SCUBA divers equipped with hand-held Hargrave core samplers (Wildish et al. 2003). The 2001 and 2002 acoustic surveying were completed 1 and $30 \mathrm{~d}$ after the groundtruthing, respectively. Each core sampled an area of $0.0263 \mathrm{~m}^{2}$ and a full core contained 6.21 of sediment. Sediment characteristics in the sampled part of Lime Kiln Bay were depositional (Milligan 1994).

Each core was photographed as described in Wildish et al. (2003), and the sediment profile images (SPI) were analyzed with Optimas (Version 6.2) software using the area tool divided by the fixed corer width to give the mean sample and redox potential depths (RPD). Images were analyzed by the method of Nilsson 
\& Rosenberg (2000) to determine the benthic habitat quality (BHQ) index. The latter is based on predetermined values (maximum of 15) for presence/absence of infauna/epifauna and RPD depths (Table 1). Sediment interface samples (the top 0 to $2 \mathrm{~cm}$ of the profile) were taken for geochemical measures of redox potential (Eh, expressed in $\mathrm{mV}$ relative to the normal hydrogen electrode) and total sulfides in pore water (expressed as mM) as described in Hargrave et al. (1997). Geochemical data corresponding to other organic enrichment indices are shown in Table 1. Subsamples were taken from each core to measure percent water content, organic matter content as \% loss on ignition at $450^{\circ} \mathrm{C}$ for $2 \mathrm{~h}$, and organic carbon and nitrogen by CHN analyses. Subsamples from thawed sediment, kept frozen before analysis, were taken in the 2001 sampling for enzyme hydrolyzable amino acids (EHAA) by the method of Mayer et al. (1995), and for determing sediment surface area by nitrogen adsorption (Mayer 1994). Non-parametric statistics (Elliot 1977) on untransformed data were used to determine differences between farm and reference sites.

The remaining sediment in each core was sieved through a $5 \mathrm{~mm}^{2}$ mesh sieve and running seawater, with the smallest mesh size being $1 \mathrm{~mm}^{2}$. Macrofauna retained were initially stored in $5 \%$ formalin in seawater, followed by $50 \%$ isopropanol. They were then identified and counted, using standard procedures adopted at the Atlantic Reference Centre, Huntsman Marine Science Centre, to the lowest possible taxon. The species/ abundance data were analyzed to detect patterns by graphical, univariate and multivariate methods (Clarke \& Warwick 2001) available in Primer software.

\section{RESULTS}

Backscatter maps identify the farm sites sampled in 2001 and 2002 (Fig. 2). The faint appearance of earlier cage deployments is seen most clearly in the upper panel, and the outline of an unused herring weir is
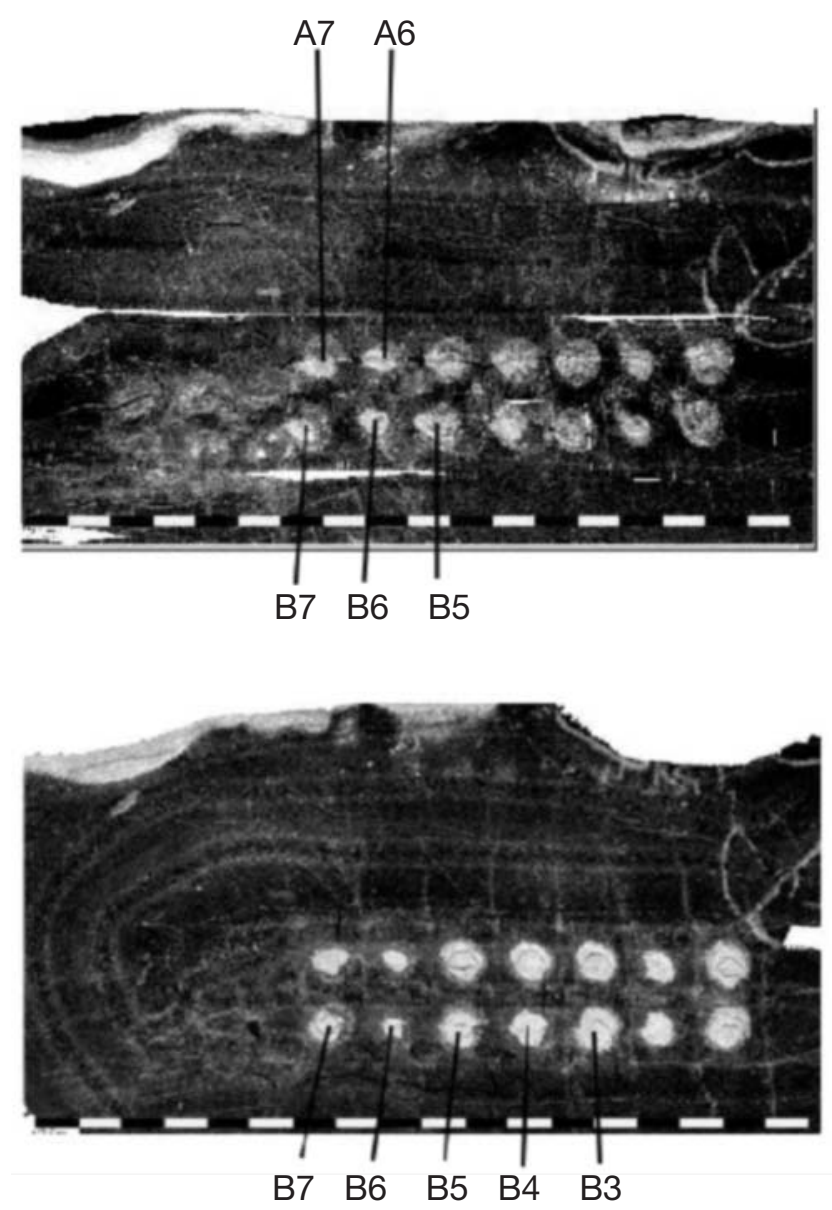

Fig. 2. Acoustic backscatter maps from 26 July 2001 (upper) determined by Knudsen sidescan and 9 October 2002 (lower) determined by a $300 \mathrm{kHz}$ multibeam sonar (vertically mounted Simrad EM3000). The 2 rows of active cages, labelled A and B, are each identified by a number from 1 to 7 (some numbers not shown). Only sampled cages are identified. The remains of 2 indistinct rows of 6 cages active until 2000 appear to the left of the labeled ones, and the remains of an old herring weir is closest to A1. The reference location is just outside the frame, below the scale bar (hatched bars at bottom) where each unit $=50 \mathrm{~m}$
Table 1. Summary of organic enrichment indices based on sedimentary observations for macrofauna of Pearson \& Rosenberg (1978), sediment profile images (SPI) and the benthic habitat quality (BHQ) of Nilsson \& Rosenberg (2000) and interfacial geochemistry of Wildish et al. (2001). Note that the degree of organicenrichment increases down the table. $\mathrm{Eh}_{\mathrm{NHE}}$ : redox potential relative to the normal hydrogen electrode

\begin{tabular}{|lcccc|}
\hline Description & Macrofauna & $\begin{array}{c}\text { Sediment profile } \\
\text { imaging BHQ }\end{array}$ & \multicolumn{2}{c|}{$\begin{array}{c}\text { Interfacial geochemistry } \\
\mathrm{Eh}_{\mathrm{NHE}}\end{array}$} \\
\hline Sulphide \\
Normal & III & $>10$ & $>100$ & $<300$ \\
Oxic & II & $5-10$ & $0-100$ & $300-1300$ \\
Hypoxic & I & $2-4$ & $-100-0$ & $1300-6000$ \\
Anoxic & 0 & $<2$ & $<-100$ & $>6000$ \\
\hline
\end{tabular}

present in both. The high backscatter areas clearly define the cage footprint, suggesting that waste food and faeces accumulate directly below the cages, with little spreading. The backscatter strength in each of the cage footprints appears to be higher in 2002 than 2001 (Table 2) by a mean value of $6.3 \mathrm{~dB}$. Possible reasons for this are that the 2001 record was tainted with echoes and shadows from the cage structures and nets. Also, there were differences in backscatter calibration on the 2 sampling dates. 
Table 2. Backscatter strengths, as mean $\mathrm{dB}$, in farm footprint and reference locations

\begin{tabular}{|lcc|}
\hline Location & 27 July 2001 & 9 October 2002 \\
\hline Farm A7 & -19.5 & \\
Farm A6 & -18.4 & \\
Farm B7 & -17.1 & -12.2 \\
Farm B6 & -18.0 & -11.8 \\
Farm B5 & -19.4 & -12.0 \\
Farm B4 & & -12.0 \\
Farm B3 & & -12.9 \\
Reference & -35.0 & -35.0 \\
\hline
\end{tabular}

Confirmation that the faint appearance of cage footprints in Fig. 2 represents an earlier cage deployment, which terminated in 2000, is shown in Fig. 3. The upper and lower panels are backscatter maps for the same area of Lime Kiln Bay in November 2000 and July 2001, respectively (the same as in the upper panel of Fig. 2). The new 2001 cage deployment saw the cages moved closer to the old herring weir, but with considerable overlap with the earlier deployment. This and other evidence with aerial photographs and backscatter maps (Hughes-Clarke et al. 2002) suggest that the areas of high backscatter may persist for 1 to $4 \mathrm{yr}$ in the sedimentary environments of Lime Kiln Bay.

All of the geochemical variables in Table 3 were examined by comparing the medians between farm and reference sites, followed by testing for differences by the Mann-Whitney $U$-test (Elliot 1977). Significant differences at $p<0.05$ were found for porosity, organic matter, carbon, nitrogen, EHAA, Eh and $\mathrm{S}^{=}$(sulfide) for both sampling dates shown in Table 3.
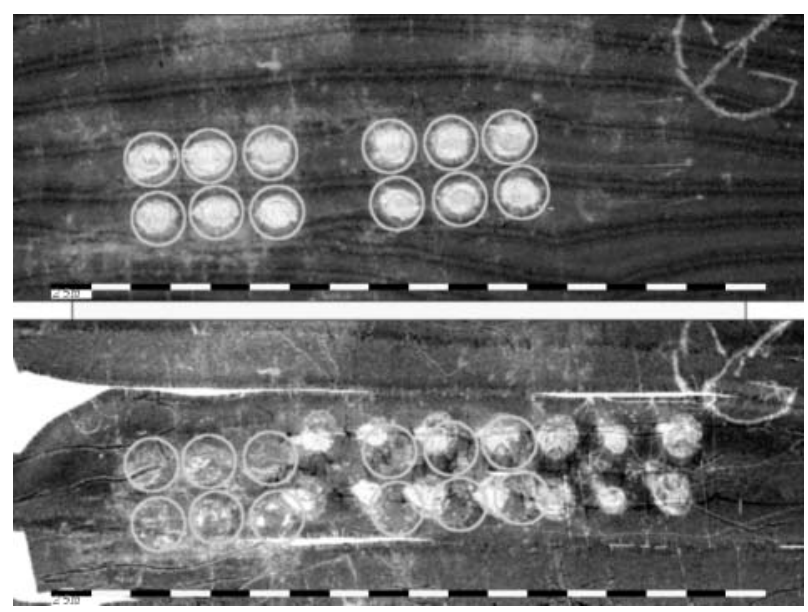

Fig. 3. Acoustic backscatter maps of November 2000 (upper), determined by a $300 \mathrm{kHz}$ multibeam sonar (vertically mounted Simrad EM3000), and 26 July 2001 (lower) determined by Knudsen sidescan. Circles indicate the position of individual cages for the earlier (1999 to 2000) deployment. Each unit of the scale bar $=25 \mathrm{~m}$
Eh is lower and $\mathrm{S}^{=}$higher in 2001 than 2002. This was unexpected because a larger volume of wastes was produced by the larger biomass of salmon in the market year (2002). It is possible that the anaerobic bacteria present in the sediment had undergone a self-poisoning event (due to high $\mathrm{H}_{2} \mathrm{~S}$ ) earlier in the summer of 2002, as found by Poole et al. (1977) and Marvin-DiPasquale \& Capone (1998). High porosity, organic matter, carbon and nitrogen contents of sediments at the farm site, coupled with relatively low sulfide levels, supports the view that the wastes were accumulating in 2002 at rates much greater than the rate of decomposition by anaerobic sulfate-reducing bacteria.

A typical SPI obtained in 2002 (Fig. 4) shows considerable build-up of non-biodegraded salmon faeces/waste food at the sediment surface of the farm site. This layer had a median depth of $13 \mathrm{~cm}$ (range 8.8 to $16.1 \mathrm{~cm}$ for all 5 cores) compared to $6.7 \mathrm{~cm}$ (range 5.2 to $10.4 \mathrm{~cm}$ ) in 2001 (not shown). Most farm images for 2002 were distinguished by white bacterial mats (Beggiatoa sp.) within this layer, suggesting that oxic/anoxic interfaces were present within it. The benthic habitat-quality indices and RPD depths for farm and reference sites (Table 4) are significantly different for both dates, based on MannWhitney $U$-tests.

We interpret the macrofauna present at the farm site (Table 4) to partly reflect recent falls from the luxuriant fouling community present on the cage structures above the sediment. The fauna is able to live in the partly re-oxygenated build-up of un-decomposed organic wastes. Multivariate analysis of macrofaunal abundance, in combination with environmental variables such as redox potential, using non-metric multidimensional scaling (nMDS), indicated that farm and reference sites clustered separately (Fig. 5) and that the bubbles were significantly larger at the farm sites. Other variables, such as sulphide, BHQ and RPD, tested in this way suggested that the bubbles were also significantly larger at farm sites (not shown). Analysis of similarities (ANOSIM) testing revealed that samples from the farm site were significantly different $(p<0.01)$ from reference sites in both years tested. Univariate tests (not shown) including the total number of taxa (Table 4), Shannon-Wiener and Pielou's eveneness, all indicated lower diversity and evenness at the farm site compared to the reference site. Graphical analysis (not shown) with $k$-dominance curves (Clarke \& Warwick 2001) suggested that biological stress was elevated at the farm site in both years. The most abundant taxon at the farm was the sludge worm Capitella capitata (Table 4), which is indicative of enriched conditions. By contrast, C. capitata was nearly absent at the reference site. 
Table 3. Summary of Lime Kiln Bay groundtruthing for interfacial geochemical variables at farm and reference sites on 2 dates. EHAA: enzyme hydrolyzable amino acids; $\mathrm{Eh}_{\mathrm{NHE}}$ : redox potential relative to the normal hydrogen electrode

\begin{tabular}{|c|c|c|c|c|}
\hline \multirow[t]{2}{*}{ Variable } & \multicolumn{2}{|c|}{26 July 2001} & \multicolumn{2}{|c|}{9 September 2002} \\
\hline & Farm & Reference & Farm & Reference \\
\hline \multicolumn{5}{|l|}{ Sediment grain size } \\
\hline \multicolumn{5}{|l|}{$\%<63 \mu \mathrm{m}$-median } \\
\hline -range & $98.79-99.60$ & $98.76-100$ & $97.27-99.68$ & $98.59-99.46$ \\
\hline \multirow{2}{*}{$\%<5 \mu \mathrm{m} \quad \begin{array}{l}\text {-median } \\
\text {-range }\end{array}$} & 42.57 & 34.00 & 40.59 & 28.56 \\
\hline & $38.14-47.86$ & $33.27-36.93$ & $36.42-47.96$ & $28.44-32.39$ \\
\hline Modal size-median & 9.19 & 13.03 & 11.34 & 16.15 \\
\hline -range & $8.00-13.93$ & $10.56-13.93$ & $8.00-13.93$ & $13.93-18.38$ \\
\hline \multirow{2}{*}{\multicolumn{5}{|c|}{$\begin{array}{c}N \\
\text { Surface area }\left(\mathrm{m}^{2} \mathbf{g}^{-1}\right)\end{array}$}} \\
\hline & & & & \\
\hline Median & 24.8 & 18.7 & & \\
\hline Range & $20.7-43.3$ & $13.2-27.5$ & & \\
\hline \multirow{2}{*}{$\mathrm{N}$} & 9 & 15 & & \\
\hline & \multicolumn{4}{|c|}{ Porosity (\%) } \\
\hline Median & 79.79 & 68.48 & 82.74 & 66.15 \\
\hline Range & $72.99-83.47$ & $61.14-77.89$ & $78.32-85.19$ & $65.21-69.71$ \\
\hline \multirow{2}{*}{\multicolumn{5}{|c|}{$\begin{array}{l}\mathrm{N} \\
\text { Organic matter (\%) }\end{array}$}} \\
\hline & & & & \\
\hline Median & 37.73 & 8.88 & 37.49 & 8.63 \\
\hline Range & $22.76-40.53$ & $7.94-10.64$ & $34.02-43.57$ & $8.52-8.82$ \\
\hline \multirow{2}{*}{\multicolumn{5}{|c|}{$\begin{array}{l}\mathrm{N} \\
\text { Organic carbon }(\%)\end{array}$}} \\
\hline & & & & \\
\hline \multicolumn{5}{|l|}{$\begin{array}{l}\text { Organic carbon (\%) } \\
\text { Median }\end{array}$} \\
\hline \multirow{2}{*}{$\begin{array}{l}\text { Range } \\
\mathrm{N}\end{array}$} & $13.71-24.42$ & $2.00-2.75$ & $21.02-25.74$ & $2.16-2.41$ \\
\hline & 5 & 12 & 4 & 4 \\
\hline \multicolumn{5}{|l|}{ Nitrogen (\%) } \\
\hline Median & 2.21 & 0.33 & 2.39 & 0.28 \\
\hline Range & $1.34-2.38$ & $0.25-0.37$ & $1.68-2.51$ & $0.26-0.31$ \\
\hline $\mathrm{N}$ & 5 & 12 & 4 & 4 \\
\hline EHAA $\left(\mathrm{mg} \mathrm{g}^{-1}\right)$ & & & & \\
\hline Median & 22.35 & 1.47 & & \\
\hline Range & $13.98-60.38$ & $0.93-1.91$ & & \\
\hline $\mathrm{N}$ & 9 & 15 & & \\
\hline $\mathrm{Eh}_{\mathrm{NHE}}(\mathrm{mV})$ & & & & \\
\hline Median & -148 & 158 & -111 & 100 \\
\hline Range & -183 to 25 & 83 to 183 & -156 to -17 & 53 to 200 \\
\hline $\mathrm{N}$ & 15 & 15 & 15 & 15 \\
\hline Sulfide $(\mu \mathrm{M})$ & & & & \\
\hline Median & 30000 & 1300 & 2500 & 350 \\
\hline Range & $13000-40000$ & $240-5000$ & $2180-8130$ & $209-813$ \\
\hline $\mathrm{N}$ & 9 & 15 & 15 & 15 \\
\hline
\end{tabular}

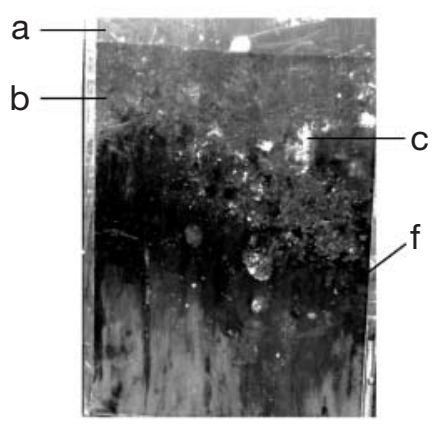

A

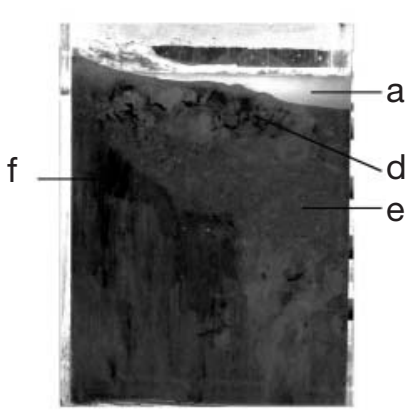

B

Fig. 4. Sediment profile images on 9 September 2002 for Farm B5 (A) and Reference Stn R2 (B). a: Seawater; b: undecomposed food and faecal wastes; c: white reflecting body, possibly Beggiatoa sp.; d: feeding voids and aerobic sediment above the redox potential discontinuity; f: black sulfide layer

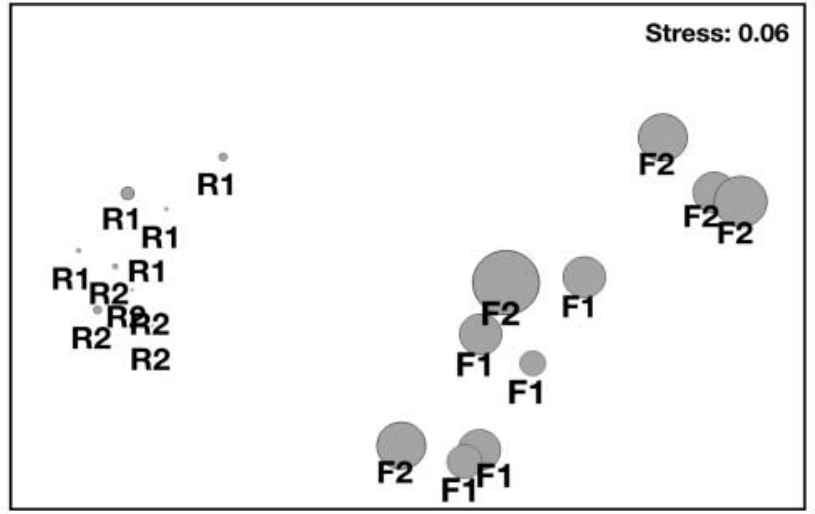

Fig. 5. Community structure non-metric multidimensional scaling (nMDS) bubble plot of farm (F) and reference (R) sites; $1=$ 2001 and $2=2002$ samplings. $N=5$ for each site. Size of the superimposed circles is proportional to redox potential negativity 
Table 4. Summary of Lime Kiln Bay groundtruthing for sediment profile imaging and macrofaunal species and density variables at farm and reference sites on 2 dates. BHQ: benthic habitat quality index; RPD: redox potential discontinuity depths

\begin{tabular}{|c|c|c|c|c|}
\hline \multirow{2}{*}{ Variable } & \multicolumn{2}{|c|}{-26 July 2001} & \multicolumn{2}{|c|}{ — 9 September 2002} \\
\hline & Farm & Reference & Farm & Reference \\
\hline \multicolumn{5}{|l|}{ BHQ } \\
\hline Median & 0 & 8 & 0 & 9 \\
\hline Range & - & $6-9$ & - & $8-10$ \\
\hline $\mathrm{N}$ & 5 & 5 & 5 & 5 \\
\hline \multicolumn{5}{|l|}{$\mathrm{RPD}, \mathrm{cm}$} \\
\hline Median & 0 & 9.9 & 0 & 11.7 \\
\hline Range & - & $8.8-13.7$ & - & $6.9-14.7$ \\
\hline $\mathrm{N}$ & 5 & 5 & 5 & 4 \\
\hline \multicolumn{5}{|l|}{ Macrofauna } \\
\hline Total species & 9 & 37 & 12 & 30 \\
\hline Range/core & $2-6$ & $13-18$ & $2-8$ & $14-17$ \\
\hline $\mathrm{N}$ & 5 & 5 & 5 & 5 \\
\hline \multicolumn{5}{|c|}{ Capitella capitata } \\
\hline Median & 30 & 0 & 1 & 0 \\
\hline Range & $5-85$ & $0-2$ & $0-25$ & - \\
\hline $\mathrm{N}$ & 5 & 5 & 5 & 5 \\
\hline
\end{tabular}

\section{DISCUSSION}

The results allow us to establish that at the mid-point of each salmon cage, which we investigated in 2001 and 2002 by conventional benthic groundtruthing methods, was highly organically enriched (see Table 1). All 3 established methods used to characterize Stage 0 organic enrichment (Table 1), i.e. macrofaunal, geochemical and sediment profile imaging, indicate that this farm site had reached the most advanced organic enrichment stage. The results for EHAA (for 2001 only) suggest that the farm site had 15 times more readily available amino acids for deposit feeders than the reference site. Differences in porosity, organic matter, carbon and nitrogen also support the view that the farm interfacial sediments are highly organically enriched.

The acoustic results allow us to reject the null hypothesis that areas of high backscatter directly under salmon farm cages are not causally related to organic enrichment events. The causal evidence between the area of high backscatter and independent measures indicating organic enrichment is circumstantial. The work presented is a necessary, but not sufficient, step in establishing that acoustic backscatter can accurately map organic enrichment. Further research needed to reach this goal includes determining (1) the geotechnical mechanism responsible for the characteristic acoustic response, e.g. acoustic reflection from methane gas bubbles within enriched sediments, increased surface roughness due to accreting wastes, or increased water content of sediments; (2) whether acoustic responses can distinguish a gradient of organic enrichment, and not just the gross changes that we have recognized here. If the geotechnical property that acoustics recognizes in enriched sediments is methane bubbles, it is likely that the method developed from it will be limited to areas of gross changes of organic enrichment. This is because methanogenesis represents a final stage in the organic enrichment process, and is associated with only the grossest changes. The observation that acoustic patterns persist over a few years, after the organic enrichment inputs cease, suggests that the methods can be used to temporally monitor recovery rates; and (3) whether backscatter contrasts apply in both depositional and erosional sediments. It is of interest that MacDougall \& Black (1999), using acoustic methods in a net erosional sediment, found no evidence of acoustic responses indicating organic enrichment.

Depending on the answers to these questions, it may be possible to develop acoustic methods as an organic enrichment mapping tool. The fieldwork involved in acoustic mapping can be achieved at rates of $5 \mathrm{~km}^{2} \mathrm{~h}^{-1}$, with additional computer processing time required to finalize acoustic maps. This method should be costeffective in time compared to classical macrofaunal sampling. The acoustic method can be used sublittorally throughout the coastal zone and for other sources of organic enrichment in sediments, and so may be of importance in integrated coastal zone management.

Efforts are already underway in many laboratories to use acoustic mapping as a more general means of defining macrobenthic communities and their typical habitats on the continental shelf (e.g. Magorrian et al. 1995, Wildish et al. 1998, Kostylev et al. 2001).

Acknowledgements. We sincerely thank the following for help in the field and lab for completing this work: Hugh Akagi, Angela Martin, Timothy Milligan, Annyah Duxfield, Georgina Phillips, Lisa Doucette, Linda Schick, Luke Aymar, Dale Tucker, Captain Wayne Miner and Danny Loveless.

\section{LITERATURE CITED}

Clarke KR, Warwick RM (2001) Change in marine communities: an approach to statistical analysis and interpretation, 2nd edn. PRIMER-E methods papers, Plymouth Marine Laboratory, Plymouth 
Cloern JE (2001) Our evolving conceptual model of the coastal eutrophication problem. Mar Ecol Prog Ser 210: $223-253$

Elliot JM (1977) Some methods for the statistical analysis of samples of benthic invertebrates. Freshwater Biological Association, Ambleside

Gowen RJ, Bradbury N (1987) The ecological impacts of salmonid farming in coastal waters: a review. Oceanogr Mar Biol Annu Rev 24:563-575

Gray JS, Wu RSS, Or YY (2002) Effects of hypoxia and organic enrichment on the coastal environment. Mar Ecol Prog Ser 238:249-279

Hargrave BT, Phillips GA, Doucette LI, White MJ, Milligan TG, Wildish DJ, Cranston RE (1997) Assessing benthic impacts of organic enrichment from marine aquaculture. Water Air Soil Pollut 99:641-650

Hughes-Clarke JE (1994) Toward remote seafloor classification using the angular response acoustic backscattering: a case study from multiple overlapping GLORIA data. IEEE J Ocean Eng 19:364-374

Hughes-Clarke JE (2001) Remote acoustic characterization of mariculture site sediments. In: Hargrave BT, Phillips GA (eds) Environmental studies for sustainable aquaculture (ESSA): 2001 workshop report. Can Tech Rep Fish Aquat Sci 2352, Dartmouth, p 42-43

Hughes-Clarke JE, Mayer LA, Wells DE (1996) Shallow-water imaging multibeam sonars: a new tool for investigating seafloor processes in the coastal zone and on the continental shelf. Mar Geophys Res 18:607-629

Hughes-Clarke JE, Wildish D, Akagi H (2002) Monitoring near-field changes at mariculture sites: a comparison between multibeam and pole-mounted sidescan. In: Hargrave BT (ed) Can Tech Rep Fish Aquatic Sci 2411, Dartmouth, p 69-73

Kostylev VE, Todd BJ, Fader GBJ, Courtney RC, Cameron GDM, Pickerill RA (2001) Benthic habitat mapping on the Scotian Shelf based on multibeam bathymetry, surficial geology and sea floor photographs. Mar Ecol Prog Ser 219: 121-137

Magorrian BH, Service M, Clarke W (1995) An acoustic bottom classification survey of Strangford Lough, Northern Ireland. J Mar Biol Assoc UK 75:987-992

Marvin-DiPasquale MC, Capone DG (1998) Benthic sulfate reduction along the Chesapeake Bay control channel. I.

Editorial responsibility: Otto Kinne (Editor),

Oldendorf/Luhe, Germany
Spatial trends and controls. Mar Ecol Prog Ser 168: $213-228$

Mayer LM (1994) Surface area control of organic carbon accumulation in continental shelf sediments. Geochim Cosmochim Acta 58:1271-1284

Mayer LM, Schick LL, Sawyer T, Plante CJ, Jumars PH, Self RI (1995) Bioavailable amino acids in sediments: a biolimnetic, kinetics based approach. Limnol Oceanogr 40: 511-520

McDougall N, Black KD (1999) Determining sediment properties around a marine cage farm using acoustic ground discrimination: Rox Ann ${ }^{\mathrm{TM}}$. Aquacult Res 30:451-458

Milligan TG (1994) Suspended and bottom sediment grain size distributions in Letang Inlet, NB, October 1990. Can Tech Rep Hydrogr Ocean Sci 156:1-51

Nilsson HC, Rosenberg R (2000) Succession in marine benthic habitats and fauna in response to oxygen deficiency: analysed by sediment-profile imaging and by grab samples. Mar Ecol Prog Ser 197:139-149

Pearson TH, Rosenberg R (1978) Macrobenthic succession in relation to organic enrichment and pollution of the marine environment. Oceanogr Mar Biol Annu Rev 16: 229-311

Poole NJ, Parkes RJ, Wildish DJ (1977) The reactions of the estuarine ecosystem to effluents from the pulp and paper industry. Helgol Wiss Meersunters 30:622-632

Poole NJ, Wildish DJ, Kristmanson DD (1978) The effects of the pulp and paper industry on the aquatic environment. CRC Crit Rev Environ Control 8:153-195

Tlusty MF, Hughes-Clarke JE, Shaw J, Pepper VA, Anderson MR (2000) Groundtruthing multibeam bathymetric surveys of finfish aquaculture sites in the Bay d'Espoir estuarine fjord, Newfoundland. Mar Tech Soc J 34: 59-67

Wildish DJ, Fader GBJ, Lawton P, MacDonald AJ (1998) The acoustic detection and characteristics of sublittoral bivalve reefs in the Bay of Fundy. Cont Shelf Res 18:105-113

Wildish DJ, Hargrave BT, Pohle GW (2001) Cost-effective monitoring of organic enrichment resulting from salmon mariculture. ICES J Mar Sci 58:369-376

Wildish DJ, Hargrave BT, MacLeod C, Crawford C (2003) Detection of organic enrichment near finfish net-pens by sediment profile imaging at SCUBA accessible depths. J Exp Mar Biol Ecol 285-286:403-413

Submitted: April 28, 2003; Accepted: October 21, 2003

Proofs received from author(s): February 2, 2004 